\title{
Transient insulin resistance following infusion of adrenaline in Type 1 (insulin-dependent) diabetes mellitus
}

\author{
M. Kollind ${ }^{1}$, U. Adamson ${ }^{1}$, P. E. Lins ${ }^{1}$ and B.Hamberger ${ }^{2}$ \\ ${ }^{1}$ Department of Medicine, Danderyd Hospital, Danderyd, and 2 Department of Surgery, Karolinska Hospital, Stockholm, Sweden
}

\begin{abstract}
Summary. Insulin resistance was assessed after an intravenous infusion of adrenaline $\left(50 \mathrm{ng} \cdot \mathrm{kg}^{-1} \cdot \mathrm{min}^{-1}\right)$ or saline (control study) given between 08.00 and 08.30 hours in nine patients with Type 1 (insulin-dependent) diabetes mellitus. The blood glucose level during a somatostatin $(100 \mu \mathrm{g} / \mathrm{h})$-insulin $\left(0.4 \mathrm{mU} \cdot \mathrm{kg}^{-1} \cdot \mathrm{min}^{-1}\right)$-glucose $\left(4.5 \mathrm{mg} \cdot \mathrm{kg}^{-1} \cdot \mathrm{min}^{-1}\right)$ infusion-test performed between 10.30 and 14.30 hours served as an indicator of the total body insulin resistance. Blood glucose was maintained around $7 \mathrm{mmol} / 1$ between 08.00 and 10.30 hours by a constant infusion of regular insulin $\left(0.57 \mathrm{mU} \cdot \mathrm{kg}^{-1} \cdot \mathrm{min}^{-1}\right)$ and a variable infusion of a $20 \%$ glucose solution. The infusion of adrenaline raised plasma adrenaline to $2.7 \pm 0.3 \mathrm{nmol} / \mathrm{l}$ (mean $\pm \mathrm{SEM}$ ) at the end of the infusion; thereafter it returned to its basal level within $30 \mathrm{~min}$. The plasma levels of free insulin, glucagon, cortisol
\end{abstract}

and growth hormone were similar in the adrenaline and the control studies from 08.00 to 14.30 hours. In comparison with the control study the infusion of adrenaline decreased the need for intravenous glucose significantly over the initial $2 \mathrm{~h}$. Furthermore, during the somatostatin-insulin-glucose infusion test the blood glucose rose significantly $(p<0.05)$ over the initial $2 \mathrm{~h}$; thereafter no significant differences between the two studies were seen. It is concluded that a short term infusion of adrenaline, resembling the adrenergic hormone response to hypoglycaemia, induces a diabetogenic effect which subsides within $6 \mathrm{~h}$ after omission of the adrenaline infusion.

Key words: Adrenaline, insulin resistance, diabetes mellitus, counterregulatory hormones, the Somogyi phenomenon.
In response to insulin-induced hypoglycaemia the secretion of adrenaline, glucagon, cortisol and growth hormone $(\mathrm{GH})$ is stimulated. Adrenaline and glucagon are essential for acute blood glucose recovery while cortisol and GH have no immediate effects [1]. In a previous study in Type 1 (insulin-dependent) patients we have demonstrated that hypoglycaemia is followed by insulin resistance for up to $12 \mathrm{~h}$ [2]. The role of each of the counterregulatory hormones in causing this phenomenon has not been established. We have previously demonstrated that $\mathrm{GH}$ exhibits a sustained diabetogenic action following a temporary increase in plasma $\mathrm{GH}$ and that cortisol acts in synergism with $\mathrm{GH}$ in this respect [3]. Whether adrenaline alone may induce such a longstanding state of insulin resistance is unclear. The aim of the present study was therefore to assess the total body insulin resistance by a somatostatin-insulin-glucose infusion test (SIGIT) for $6 \mathrm{~h}$ following a short-term infusion of adrenaline in patients with Type 1 diabetes.

\section{Subjects and methods}

\section{Subjects}

Nine male diabetic patients, aged $20-44$ years, without residual Bcell function (C-peptide $<0.15 \mathrm{nmol} / 1$ after a mixed meal) were studied. The duration of their diabetes was $12.3 \pm 1.9$ years, their body mass index (4) $22.9 \pm 0.7$ and their glycosylated haemoglobin concentration $\left(\mathrm{HbA}_{1 \mathrm{c}}\right.$ ) was $7.5 \pm 0.4 \%$ (normal range $<5.6 \%$ ). The daily insulin dose was $46.7 \pm 3.3 \mathrm{U}$ divided into two, three or four injections. The plasma levels of antibody-bound insulin ranged from zero to $11 \%$ in all but two patients who had 19 and $26 \%$ respectively. None had hypertension, albuminuria or signs of peripheral neuropathy and their autonomic nervous function assessed by the Valsalva ratio [5] and respiratory sinus arrhythmia [6] was normal. None was taking medication other than insulin. The subjects were recruit- 
ed from our out-patient clinic and were not selected on the basis of previous manifestations of metabolic brittleness. Informed consent was obtained from all subjects and the local Ethics Committee approved the study.

\section{Study protocol}

The last subcutaneous insulin injection was given $34-36 \mathrm{~h}$ prior to the study. The patients were admitted to a metabolic ward $24 \mathrm{~h}$ before the study and thereafter blood glucose was controlled by an i.v. insulin infusion (Actrapid, Novo Industri $\mathrm{A} / \mathrm{S}$, Copenhagen, Denmark), adjusted every $1-3 \mathrm{~h}$ according to the capillary blood glucose concentration, aiming at a level of $10 \mathrm{mmol} / 1$. The patients had their regular meals and snacks during this period (day 1) but no food was ingested after 22.00 hours. The insulin infusion allowed the patients to walk inside the hospital but not to perform heavy exercise. On the following morning (day 2) between 06.00 and 08.00 hours blood glucose was adjusted to a level of approximately $7 \mathrm{mmol} / \mathrm{l}$. The patients were placed in a comfortable semirecumbent position and a short teflon catheter was inserted into a forearm vein on each side, one being used for blood sampling and the other for hormone infusions. Between 08.00 and 10.30 hours the blood glucose level was clamped at $7 \mathrm{mmol} / 1$ by means of a variable $20 \%$ glucose i.v. infusion and a constant rate i.v. infusion of insulin $\left(0.57 \mathrm{mU} \cdot \mathrm{kg}^{-1} \cdot \mathrm{min}^{-1}\right)$. In separate studies adrenaline $(50 \mathrm{ng}$. $\mathrm{kg}^{-1} \cdot \mathrm{min}^{-1}$ ) or saline was given as an i.v. infusion between 08.00 and 08.30 hours. In both studies at 10.30 hours the ongoing infusion of insulin and glucose was replaced by an i.v. somatostatin $\left(100 \mu \mathrm{g} / \mathrm{h}\right.$, Ferring $\mathrm{AB}$, Malmö, Sweden)-insulin $\left(0.4 \mathrm{mU} \cdot \mathrm{kg}^{-1}\right.$. $\left.\min ^{-1}\right)$-glucose $\left(4.5 \mathrm{mg} \cdot \mathrm{kg}^{-1} \cdot \mathrm{min}^{-1}\right)$-infusion test (SIGIT) terminated at 14.30 hours. Each patient participated in two studies, i.e. with and without infusion of adrenaline, performed in random order separated by at least one week.

\section{Analytical procedures}

Venous blood samples were obtained every 5-60 min between 08.00 and 14.30 hours for measurements of the concentration of blood glucose (Glucose analyzer $23 \mathrm{AM}$, Yellow Spring Instruments, Yellow Springs, Ohio, USA), free insulin [7], GH [8], cortisol [9], glucagon [10] and adrenaline [11]. The glycosylated haemoglobin con-

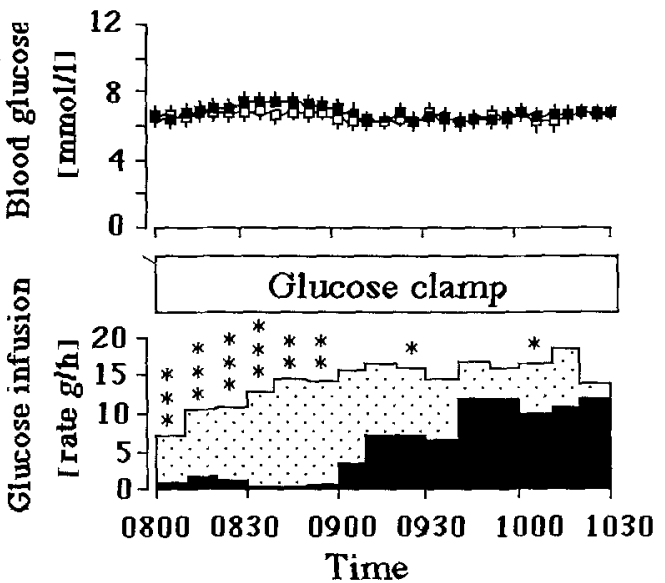

Fig. 1. The effect of the adrenalin infusion (08.00-08.30 hours) on blood glucose level and glucose infusion rate during the glucose clamp (08.00-10.30 hours). Upper panel: The blood glucose level with ( $\square$ ) and without ( $\square-\square$ ) adrenaline infusion. Lower panel: The glucose infusion rate denoted for each $10 \mathrm{~min}$ period with (E) and without (중) adrenaline infusion. ${ }^{*} p<0.05,{ }^{* *} p<0.01$, $* * * p<0.001$
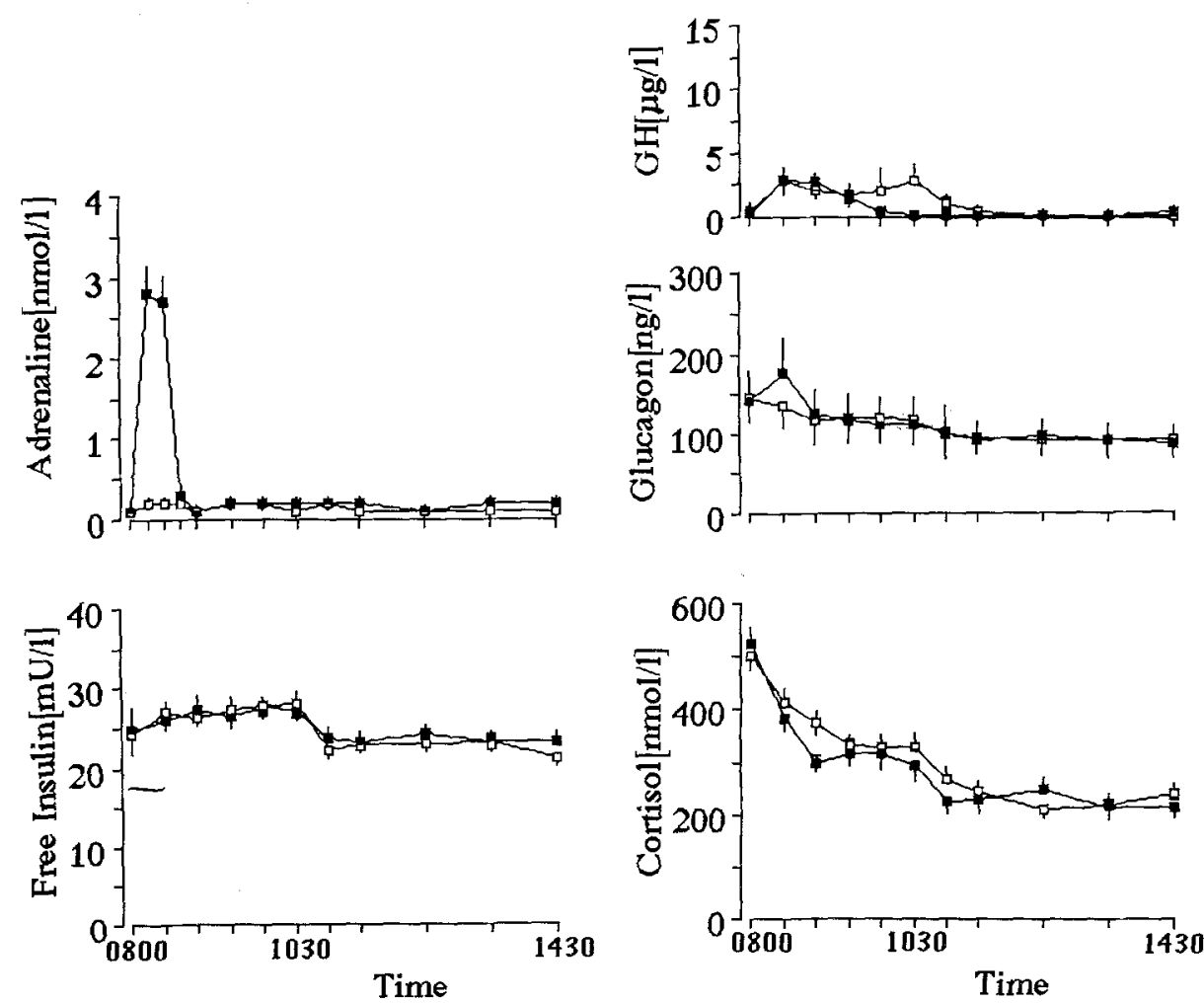

Fig. 2. Plasma adrenaline, free insulin, growth hormone, glucagon and cortisol levels during the glucose clamp (08.0010.30 hours) and the somatostatininsulin-glucose infusion test $(10.30$ 14.30 hours) in the study with ( - ) and without $(\square-\square)$ adrenaline infusion 
centration [12], the plasma level of anti-body bound insulin [7], Cpeptide [13] and the index of blood glucose fluctuations (M-value) [14] were determined in each patient.

\section{Statistical analysis}

Unless otherwise stated all data are given as means \pm SEM. Statistical significance was calculated by using Wilcoxon's signed rank test for paired observations.

\section{Results}

The mean blood glucose and M-value during the $24 \mathrm{~h}$ period prior to the studies ranged from $9.3 \pm 0.3$ to $9.6 \pm 0.3 \mathrm{mmol} / 1$ and from $18.0 \pm 2.8$ to $21.2 \pm 2.30$, respectively, with no differences between the adrenaline and the control study.

Between 08.00 and 10.30 hours, i.e. the glucoseclamp period, the blood glucose level was close to $7 \mathrm{mmol} / 1$ in both studies (Fig. 1 ) and there were no significant differences in plasma free insulin, $\mathrm{GH}$, glucagon and cortisol (Fig.2). The infusion of adrenaline raised its plasma level to $2.7 \pm 0.3 \mathrm{nmol} / 1$ at end of the infusion at 08.30 hours; thereafter, it rapidly declined reaching the basal level within $30 \mathrm{~min}$ (Fig.2). As expected, in the adrenaline study only minimal amounts of glucose had to be infused initially while glucose had to be given continuously in the study without adrenaline to keep the blood glucose close to $7 \mathrm{mmol} / 1$. This difference in glucose infusion rate between the two studies decreased over time (Fig.1). In response to the adrenaline infusion the patients recognised mild palpitation and their heart rate increased from a basal of $69 \pm 3$ to $76 \pm 3$ beats/ $\mathrm{min}, p<0.05$.

During the SIGIT close to identical levels of plasma free insulin and counterregulatory hormones were registered (Fig. 2). The blood glucose rose significantly $(p<0.05)$ during the initial $2 \mathrm{~h}$ of the SIGIT in the adrenaline as compared to the control study; thereafter this difference declined and was not statistically significant from $3 \mathrm{~h}$ after start of the SIGIT (Fig.3).

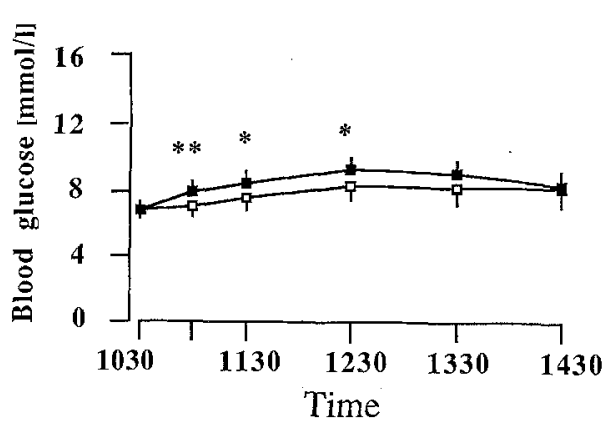

Fig. 3. The effect of the adrenalin infusion (08.00 08.30 hours) on the blood glucose level during the somatostatin-insulin-infusion test $(10.30-14.30$ hours) in the study with $(-\square)$ and without $([-\square)$ adrenaline infusion. ${ }^{*} p<0.05, * * p<0.01$

\section{Discussion}

The aim of the present study was to clarify whether a transient increase in plasma adrenaline alone could induce a long-standing state of insulin resistance as analysed by a somatostatin-insulin-glucose infusion test (SIGIT) [2]. The infusion of adrenaline yielded a plasma adrenaline profile similar to that seen during insulin-induced hypoglycaemia [1] and exerted a diabetogenic effect which was, however, not demonstrable $4.5 \mathrm{~h}$ after normalisation of the plasma adrenaline level. These findings are in accordance with the known ability of adrenaline to exert its diabetogenic action rapidly after its plasma level is raised [15].

Although data is lacking demonstrating whether the diabetogenic effect of adrenaline persists for several hours after its circulatory levels are normalised, some authors have proposed that adrenaline is the main factor behind posthypoglycaemic hyperglycaemia (the Somogyi phenomenon) [16, 17]. Thus Popp and co-workers [16] referred posthypoglycaemic hyperglycaemia to increased sympathoadrenal activation since they found that posthypoglycaemic hyperglycaemia was attenuated in Type 1 diabetic patients by the unselective beta-adrenergic blocker propranolol. Their study period was relatively short, however, not exceeding $2 \mathrm{~h}$ following nadir hypoglycaemia. Attvall and co-workers [17] have also reported that propranolol prevents posthypoglycaemic insulin resistance in Type 1 diabetic patients during a time period of $2.5 \mathrm{~h}$ following the hypoglycaemic event. Both these studies demonstrate the importance of adrenaline for the acute recovery of blood glucose but cannot evaluate the mechanism behind longstanding posthypoglycaemic insulin resistance, i.e. a time period of at least $6 \mathrm{~h}$ after hypoglycaemia [2, 18]. Kleinbaum and coworkers [19] have also studied the effect of propranolol on the plasma glucose homeostasis after insulin-induced hypoglycaemia in Type 1 diabetic patients. Their study period covered $5 \mathrm{~h}$ after nadir hypoglycaemia. The counterregulatory hormone response was similar during propranolol infusion apart from the expected potentiated secretion of $\mathrm{GH}$ induced by the drug. Interestingly, the recovery of plasma glucose was blunted for about $3 \mathrm{~h}$ by propranolol; thereafter this effect of the drug was no longer evident. The impairment of glucose recovery was due to a smaller reduction in peripheral glucose uptake, while hepatic glucose production was not modified. Thus, their study again demonstrates the importance of adrenaline for blood glucose recovery in Type 1 diabetic patients but speaks against the importance of adrenaline in causing the Somogyi phenomenon. Moreover, since unselective beta-blockers do not only counteract the action of adrenaline but also potentiate the release of GH during hypoglycaemia $[19,20]$, it is questionable whether the metabolic effects of adrenaline itself could be ader quately assessed by beta-blockers. This may be of par- 
ticular importance in prolonged studies since $\mathrm{GH}$ alone induces insulin resistance after a lag period of

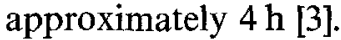

It has been demonstrated that adrenaline infusion may enhance the secretion of pancreatic glucagon [21]. Against this background it is of importance to notice that in the present study adrenaline infusion did not influence the plasma levels of counterregulatory hormones or plasma free insulin significantly. Therefore the diabetogenic effect of adrenaline registered here is probably caused by its direct effects on the liver and peripheral tissues.

We conclude that a $30 \mathrm{~min}$ i.v. infusion of adrenaline mimicking its response to hypoglycaemia exerts a diabetogenic effect which in well-insulinised Type 1 diabetic patients subsides within $6 \mathrm{~h}$. It is therefore unlikely that adrenaline is a major factor in causing longstanding insulin resistance after hypoglycaemia.

Acknowledgements. We wish to thank Ms. A. Ekelund, Mrs. U.Enberg, Prof. S. Efendic and Assist. Prof. T. Curstedt for their help in this study, which was supported by the Swedish Medical Research Council $(19 x-6589$ and $19 x-2330)$, the Swedish Diabetes Association, the Karolinska Institute, EIRS 50-year foundation and the Novo Research Institute.

\section{References}

1. Rizza RA, Cryer PE, Gerich JE (1979) Role of glucagon, catecholamines, and growth hormone in human glucose counterregulation. Effects of somatostatin and combined alpha and beta adrenergic blockade on plasma glucose recovery and glucose flux rates after insulin-induced hypoglycaemia. J Clin Inves 64: 62-71

2. Kollind M, Adamson U, Lins PE (1987) Insulin resistance following nocturnal hypoglycemia in insulin-dependent diabetes mellitus. Acta Endocrinol 116: 314-320

3. Kollind M, Adamson U, Lins PE, Efendic S (1987) Diabetogenic action of $\mathrm{GH}$ and cortisol in insulin-dependent diabetes mellitus. Aspects of the mechanisms behind the Somogyi phenomenon. Horm Metab Res 19: 156-159

4. Thomas AE, Kay DA, Cutlip MB (1976) A nomograph method for assessing body weight. Am J Clin Nutr 29: 302-304

5. Page MM, Watkins PJ (1978) Cardiorespiratory arrest and diabetic autonomic neuropathy. Lancet: $14-20$

6. Angelone A, Coulter NA (1964) Respiratory sinus arrhytmia: a frequency dependent phenomenon. J Appl Physiol 19: 479-482

7. Nakagawa S, Nakayama H, Sasaki T, Yoshino K, Yu YY, Shinozaki K, Aoki S, Mashimo K (1973) A simple method for the determination of serum free insulin levels in insulin treated patients. Diabetes 22: 590-600
8. Cerasi E, Della Casa L, Luft R, Roovete A (1966) Determination of human growth hormone (HGH) in plasma by a double antibody radioimmunoassay. Acta Endocrinol (Copenh) 53: $101-120$

9. Lantto O, Lindbäck B, Aakvaag A, Damkjaer-Nielsen M, Pomoell UM, Björkhem I (1983) Assay of cortisol with a radioimmunoassay method calibrated by isotopic dilution mass-spectrometri. A nordic collaborative study. Scand J Clin Invest 43: 433-477

10. Faloona GR, Unger RH (1974) Glucagon. In: Jaffe BM, Behrman HR (eds) Methods of hormone radioimmunoassay. Academic Press, New York London 317-330

11. Hallman H, Farnebo LO, Hamberger B, Jonsson G (1978) A sensitive method for determination of plasma catecholamines using liquid chromatography with electrochemical detection. Life Sci 23: 1049-1052

12. Jeppson JO, Franzen B, Nilsson KO (1978) Determination of glycosylated hemoglobin fraction $\mathrm{HbA} 1 \mathrm{c}$ in diabetes mellitus by thin-layer electro-focusing. Science Tools 25: 69-72

13. Heding JG (1975) Radioimmunological determination of human C-peptide in serum. Diabetologia 11: $541-548$

14. Schlichtkrull J, Munck O, Jersild M (1965) The M-value, an index of blood glucose control in diabetics. Acta Med Scand 177: 95-102

15. Rizza RA, Cryer PE, Haymond MW, Gerich JE (1980) Adrenergic mechanisms for the effects of epinephrine on glucose production and clearance in man. J Clin Invest 65: 682-689

16. Popp DA, Shah SD, Cryer PE (1982) Role of epinephrinemediated beta-adrenergic mechanisms in hypoglycemic glucose counterregulation and posthypoglycemic hyperglycemia in insulin-dependent diabetes mellitus. I Clin Invest 69: 315-326

17. Attvall S, Fowelin J, von Schenk H, Lager I, Smith U (1987) Insulin resistance in Type 1 (insulin dependent) diabetes following hypoglycaemia-evidence for the importance of beta-adrenergic stimulation. Diabetologia 30: 691-697

18. Bolli GB, Gottesman IS, Campbell PJ, Haymond MW, Cryer PE, Gerich JE (1984) Glucose counterregulation and waning of insulin in the Somogyi phenomenon (posthypoglycemic hyperglycemia). N Engl J Med 311: 1214-1219

19. Kleinbaum J, Shamoon H (1984) Effect of propranolol on delayed glucose recovery after insulin-induced hypoglycemia in normal and diabetic subjects. Diabetes Care 7: 155-162

20. Blackard WG, Heidingsfelder SA (1968) Adrenergic receptor control mechanisms for growth hormone secretion. J clin Invest 47: 1407-1414

21. Benson JW, Johnson DG, Palmer JP, Werner PL, Ensinck JW (1977) Glucagon and catecholamine secretion during hypoglycemia in normal and diabetic man. $\mathrm{J}$ Clin Endocrinol Metab 44: $459-464$

Received: 26 January 1988

and in revised form: 16 May 1988

Dr. M. Kollind

Department of Medicine

Danderyd Hospital

S-182 88 Danderyd, Stockholm

Sweden 